\title{
Reducing Plagiarism among the Students' Essays in the Light of Ethical Perspective
}

\author{
Halim Wiryadinata ${ }^{1}$, Jootje Musa Pankey ${ }^{2}$ \\ 1, 2Sekolah Tinggi Teologi Pelita Bangsa, Jakarta \\ ${ }^{1}$ ketua@sttpb.ac.id
}

\begin{abstract}
An essay is one of the assignments that have been given by the lecturers to the students involved in the subject. However, the given essay is done by the undergraduate students of Sekolah Tinggi Teologi Pelita Bangsa contained as the plagiarism work, which is analyzed by the Turnitin tool. Plagiarism is committed among 27\% - 35\% as found through the Turnitin tool and it seems to increase gradually every semester. This "criminal work" needs to be minimalized, where the standard of Sekolah Tinggi Teologi Pelita Bangsa is being set up and must be met by the Word of God which says, "Do not steal." If the problem is not sorted out then the increasing number of plagiarisms threatens the academic standard of academicians at ST Pelita Bangsa. Therefore, this research must be conducted through careful analysis via qualitative methodology by interviewing the students and the lecturers. The finding is that students don't know how to write an essay due to the lack of practicing from the beginning of the new academic year and the limited number of books at the library is the motive for the students doing it. The latter recommendation must be done to prevent the increase of plagiarism.
\end{abstract}

Keywords: literation; plagiarism; students' essays; STT Pelita Bangsa; Turnitin

\section{INTRODUCTION}

A piece of work in the academic standard must reflect upon the independency of a person when he/she does the work. The work must not cite another's work without acknowledging where the source is taken from. The acknowledgement of the source must be inserted to approve someone's idea upon the work. In other words, if the author does not acknowledge where the source is from then it must be written off as plagiarism.

The increasing number of plagiarisms, which is $27 \%-79 \%$ in Sekolah Tinggi Teologi Pelita Bangsa, is done by the undergraduate students and indicating the danger of the academic independency of the authors of the books or articles. The acknowledgement of the source is very rarely stated by the undergraduate students of Sekolah Tinggi Teologi Pelita Bangsa within their work. If this is so, then the problem of plagiarism in the academic way won't be prevented in Sekolah Tinggi Teologi Pelita Bangsa. The above numbers seem to be 'alert' for the plagiarism among the work of students. The data is used in Turnitin Tool indicating that the undergraduate students of Sekolah Tinggi Teologi Pelita Bangsa plagiarise around 27\% - 79\% and the number of that seems to be prevented. Otherwise, it will ruin the credibility of Sekolah Tinggi Teologi Pelita Bangsa as an accredited institution. 
The plagiarism 'disease', however, must be dealt with by careful treatment to minimalize it in order to appreciate someone's knowledge in the academic standard. Finding out the motive and the reasons beyond the action must be revealed through this research in order to give out the possible solutions for the leaders at Sekolah Tinggi Teologi Pelita Bangsa. This leads us to identify some of the problems which may appear during the research such as: the lack of writing knowhow, the lack of resources, especially books, no socialization of writing, Indonesian tradition of education and the ease of access to technology.

The research question for this investigation is to focus on the lack of knowledge of writing for the students of Sekolah Tinggi Teologi Pelita Bangsa and the motive beyond the action of doing it. Therefore, this investigation will suggest how to reduce plagiarism among the students in Sekolah Tinggi Teologi Pelita Bangsa. In other words, the aim of this research is to suggest some possible solutions to help in reducing the plagiarism among the written essay for the students at Sekolah Tinggi Teologi Pelita Bangsa and the leaders to make some actions to prevent it. Another thing to consider also is the urgency of the research, focusing on the matter of plagiarism from the perspective of first language speakers in Sekolah Tinggi Teologi Pelita Bangsa. The other point is to prevent the increasing number of plagiarisms among the students of Sekolah Tinggi Teologi Pelita Bangsa. Otherwise, the increasing amount of cheating will ruin the reputation of this educational institution. Therefore, it needs to be considered as the urgent matter to be dealt with.

\section{METHODS}

\section{Sample}

The sampling method is a census sampling in this study. The questionnaire was distributed to all 40 students and 3 academic positions at Sekolah Tinggi Teologi Pelita Bangsa, and the response rate is $65 \%(N=40)$. Of them, $88.5 \%$ are students from Theological Program and $11.5 \%$ are students from the Christian Education Program. The research also takes qualitative research by interviewing 3 top leaders in the academic positions.

\section{Design}

This is a mixed method case study having a survey research design. To gather data a questionnaire was developed by researchers. The initial pool of 14 items was drawn from the detailed review of questions. After analyzing the item pool, and conducting the pilot test, the number of items was still up to 14 questions. Furthermore, the plagiarism test was conducted to explore the participants' basic knowledge about plagiarism as a second scale. There were 16 students in the test of making essays. The test was developed by considering the first and the second levels of Bloom's taxonomy of cognitive domain which are knowledge and comprehension levels. The original test items were taken from the "Turnitin.com" with permission. Finally, the items' clarity and lengthiness were redesigned after conducting the pilot test. 


\section{RESULTS AND DISCUSSION}

This investigation for plagiarism among the students at Sekolah Tinggi Teologi Pelita Bangsa goes along with the numbers that is stated above. This research is going to look at the specific population at Sekolah Tinggi Teologi Pelita Bangsa and hopefully it will generate data for the bigger area of Sekolah Tinggi Teologi in Indonesia. The previous research talks about how the second language speakers do plagiarism in their essays, but the previous research does not deal with how the first speaker does plagiarism. Here then, our investigation deals with the first speakers and to find out the motives including some possible solutions to avoid plagiarism.

One of the criminals in the academic site is plagiarism, where it states it to be "literary theft", and is explained as coming from the English word "plagiary" ("one who wrongfully takes another's words or ideas'), derived from the Latin plagarius ('kidnapper, seducer, plunderer, literary thief'), from plagium (kidnapping) from plaga (snare, net). ${ }^{1}$ The Compact Oxford English Dictionary (2009) defines plagiarism as the act of "taking the work or idea of someone else and pass it off as one's own." In literature, plagiarism is defined as "a form of intellectual theft" 2 and "academic dishonesty" 3 . As a result, plagiarism, according to Eret and Gokmenoglu, is a growing problem that sticks to the ethical norms. ${ }^{4}$ In other words, plagiarism is not a simple matter, but a deeper issue in the academic site. ${ }^{5}$

From what has been said above, the motive for doing plagiarism is based on the notion of the doers. Therefore, Arista and Listyani, cited by Schutz, comment that doing plagiarism is based on the motives. They also depend heavily upon the theory of Alfred Schutz, which is about the action theory. According to Alfred Schutz, the action is based on two motives, which are in order to motive and because of motive. ${ }^{6}$ In order to motive is about how the situation of the doer wants to achieve his aim in the future, while because of motive is the past condition of the doer and represents the reality of the past. Finally, the result of their research about the motives is the condition of the lecturer: lack of control, lack of knowledge, and ease of internet access. ${ }^{7}$

According to the research's case at Sekolah Tinggi Teologi Pelita Bangsa, there is a lack of knowledge for students in doing the quoting of the data. The data tells that $46.2 \%$ students do not understand how to make an academic quotation, even though $53.8 \%$ understand how to make an academic quotation. However, the data also reveals that

\footnotetext{
${ }^{1}$ R.K Barnhart, Chambers Dictionary of Etymology (Edinburgh: Chambers, 1988). 801.

${ }^{2}$ P. Ashworth, P., Bannister, P., \& Thorne, "Guilty in Whose Eyes? University Students' Perceptions of Cheating and Plagiarism in Academic Work and Assessment," Studies in Higher Education 22, no. 2 (1997): 187-203., 200.

${ }^{3}$ S Wilhoit, Helping Students Avoid Plagiarism (College Teaching, 42., 1994).

${ }^{4}$ T Eret, E. and Gokmenoglu, "Plagiarism in Higher Education: A Case Study with Prospective Academicians.," Procedia - Social and Behavioral Sciences 2, no. 2 (2010): 3303-3307.

${ }^{5}$ W. Sutherland-Smith, "Pandora's Box: Academic Perceptions of Student Plagiarism in Writing," Journal of English for Academic Purposes 4, no. 1 (2005): 83-95.

${ }^{6}$ A Schutz, The Problem of Social Reality (Dordrecht: Kluwer Academic, 1990).

${ }^{7}$ L Sarlauskiene, L. and Stabingis, "Understanding of Plagiarism by the Students in HEIs of Lithuania," Procedia - Social and Behavioral Sciences 110 (2014): 638-646.
} 
students do plagiarism for $86.4 \%$ of the students at STT Pelita Bangsa. $86.4 \%$ gives the idea of doing plagiarism at Sekolah Tinggi Teologi Pelita Bangsa becoming alert for all the civitas academics of Sekolah Tinggi Teologi Pelita Bangsa.

The data confirms that all Academic Programs give the overview to avoid plagiarism and it is $92.6 \%$, but on the other hand the lecturers do not help students to avoid plagiarism, $74.1 \%$. This prompts the question: where does it mislead? The limitation of the books in the library also contributes for the students doing plagiarism, which is $61.2 \%$ saying that the limitation of the books and just 30.8\% saying the books are good enough to support their essays. Therefore, the data tells that Sekolah Tinggi Teologi Pelita Bangsa needs to upgrade the books for each academic year.

The motive beyond the plagiarism, at Sekolah Tinggi Teologi Pelita Bangsa, varies among the students. Furthermore, the motive of doing it is along with Arista and Listyani among the Pelita Bangsa's students, which is lack of knowledge and the lack of control of the lecturers. Therefore, they do plagiarism to get the essay done as quickly as possible, but it is supported by a lack of knowledge about plagiarism. This also connects to the data which the researchers conduct through the questionnaire.

According to the data, the respondents also do not show the same pattern of making the essays, where the lecturers claim that they teach the students. The answering of the respondents shows the uncertainty of the students in using methodological research. It leads to the inconsistency of teaching how to write essays among the students of Sekolah Tinggi Teologi Pelita Bangsa. This contradicts against the data where the respondents claim $(92.6 \%)$ that they have been taught how to write essays. The inconsistency can be seen from the answering of the respondents, where one and the other do not have the similarity in answering.

Regarding the knowledge of plagiarism, the respondents understand the definition of plagiarism and it consists $100 \%$ in the data. They also can recite the definition of plagiarism perfectly, but the data shows the knowledge of citation is $55.6 \%$, who claim that they know how to make citation and $44.4 \%$ claiming they do not understand how to make citation. Apart from that, the data also gives the overview that $85.2 \%$ has done plagiarism by copying and pasting from the sources without acknowledging the authors. They have done plagiarism by presenting the reasons beyond of it. Some respondents answer that it is due to the lack of knowledge and the lack of control. The lecturers also do not notice when they have got the essays from the students, where they apparently use the other past work to submit the essay.

Regarding the ethical position, plagiarism is not appropriate conduct and it is against the law of God and academic rules. The word of ethics derives from the Greek word, which is 'ethos' --- meaning 'character' and the word also is known as moral philosophy, because it is a branch of philosophy that involves systematizing, defending and recommending concepts of right and wrong. ${ }^{8}$ In other words, ethics is the discipline that deals with what is good and bad and with moral duty and obligation. Ethics needs an

\footnotetext{
${ }^{8}$ Joseph W Weiss, Business Ethics (California: Berett-Koehler Publishers, 2014).
} 
understanding to make differences between right and wrong thinking and actions using principled decision making to choose action that do not hurt others. ${ }^{9}$ Therefore, according to Weiss, there are three general areas to be considered as a framework for understanding ethical theories: metaethics, normative ethics and descriptive ethics. Firstly, metaethics regards as one ethical principle focuses on the universal truths, the will of God, the role of reason in ethical judgement and the meaning of ethical terms. Secondly, normative ethics is more practical to prescribe and evaluate ethical behaviors in the future. Thirdly, descriptive ethics is to examine what people's beliefs and principles to present and describe the facts, events and ethical actions in specific situation and places. ${ }^{10}$

Additionally, superb ethical behavior is the main important of the message of religion principles, which is an essential base used as a rule for the religion system of life. This condition implies that the superb value of being human in the society is measured with ethics. ${ }^{11}$ Research also indicates that faith, interrelationship with followers of other faith, socialization and self - ethics are the main component in the ethical behavior. ${ }^{12}$ Paul Tillich, who is cited in the book of Weiss, insists that ethical principles alone cannot answer in serious ethical dilemmas or crises. ${ }^{13}$ Therefore, learning to think, reason and act ethically helps people to be aware of and recognize potential ethical problem.

Plagiarism, as it is defined, is the collection of private, commercial oriented or profit oriented group of people or personal, ranging in size from one - person proprietorship to corporate giants. Plagiarism also applies the partnership and corporations among the individuals in different size proprietorship. ${ }^{14}$ In other words, the influence of culture makes plagiarism to be significant feature to be success in the world of academic.

The matter of ethics in academic is a cost for the company itself due to the surrounding their activities. Doing the right thing is a matter for the enterprise to uphold legally and ethically for the relationship, reputation, morale and productivity. Otherwise, the deterioration of relationship, reputation and productivity will be the highest cost that company should have paid due to the unethical conduct. Firstly, to choose what the laws should be and whether to follow them. Secondly, to choose about economic and social issues outside the domain of law. Thirdly, to choose of the individual's interest over the academic's interest. ${ }^{15}$ Therefore, plagiarism ethics should be considered with five fundamental principles in reasoning dilemmas in complex situation. The fundamental

\footnotetext{
${ }^{9}$ Archie B. Carroll and Ann K. Buchholtz, Business \& Society (Ohio: South-Western Cengage Learning, 2009).

${ }^{10}$ Weiss, Business Ethics.

${ }^{11} \mathrm{~K}$ Laeheem, "Causal Relationships between Religion Factors Influencing Ethical Behavior among Youth in the Three Southern Border Provinces Of," Children and Youth Services Review (2019): 104641, https://doi.org/10.1016/j.childyouth.2019.104641.

${ }^{12}$ Ibid.

${ }^{13}$ Weiss, Business Ethics.

${ }^{14}$ Carroll and Buchholtz, Business \& Society.

${ }^{15}$ Laura Nash, Good Intentions aside: A Manager's Guide to Resolving Ethical Problem (Boston: Business School Press, 1990).
} 
principles in plagiarism ethics are utilitarianism, universalism, rights, justice and ethical virtue. ${ }^{16}$

\begin{tabular}{|l|l|}
\hline Principles Ethics & Meaning \\
\hline Utilitarianism & $\begin{array}{l}\text { Moral authority is determined by the consequences of an act. An } \\
\text { act is morally right if the net benefits over costs are greatest for } \\
\text { the majority }\end{array}$ \\
\hline Universalism & $\begin{array}{l}\text { Moral authority is determined by the extent to which the } \\
\text { intention of an act treats all persons with respect. }\end{array}$ \\
\hline Rights & $\begin{array}{l}\text { Moral authority is determined by individual rights guaranteed to } \\
\text { all in their pursuit of freedom speech, choice, happiness and self- } \\
\text { respect. }{ }^{19}\end{array}$ \\
\hline Justice & $\begin{array}{l}\text { Moral authority is determined by the extent opportunities, } \\
\text { wealth, and burdens are fairly distributed among all }\end{array}$ \\
\hline Virtue Ethics & $\begin{array}{l}\text { Moral authority is based on individual character virtues such as } \\
\text { truthfulness, integrity and honesty. }\end{array}$ \\
\hline
\end{tabular}

In looking from what it has been said above, then it leads us to see the interlock how ethics links to the value of what the society makes up in their culture and the culture itself judges what is good and bad, right and wrong, and lawful and unlawful based on the religious scripture in the context of religious texts. In other words, religious scripture is a factor that contributes to causal factor that influence business ethics among the companies. Each action of the employees does in the work or towards to others, it certainly connects to the religious beliefs of what he or she believes in as their ideology. Therefore, plagiarism in STT Pelita Bangsa should be warned as the highest criminal in academic site. For the leaders of STT Pelita Bangsa should be aware of this and do the changes according to our advices.

\section{CONCLUSION}

Plagiarism is one of the most dangerous criminal actions in the academic site, where it needs to be eliminated by several preventive actions. Looking at the experiences at Sekolah Pelita Bangsa, there are some practical actions to be done. They are reducing plagiarism by teaching how to make an essay before the new term begins and teaching how to make a citation, Sekolah Tinggi Teologi Pelita Bangsa should add some more references for each new semester by budgeting and looking at the policy of giving essays for each subject. In this way, the awareness and consciousness might help to stop this increasing problem of the age.

\footnotetext{
${ }^{16}$ Weiss, Business Ethics., 55

${ }^{17}$ Ibid., 56.

${ }^{18}$ Ibid., 57.

${ }^{19}$ Ibid.

${ }^{20}$ Ibid., 58.

${ }^{21}$ Ibid.
} 


\section{ACKNOWLEDGEMENT}

We would like to convey our thankfulness to Sekolah Tinggi Teologi Pelita Bangsa for the sponsoring our research for the year 2019. Thank you for Jootje Musa Pankey, who becomes my partner to do the research. We also would like to mention about our reviewers Dr. Rama Tulus Pilakoannu, M. Si dan Yulius Yusak Ranimpi, M.si, Ph. D, who give us a wonderful insight for our research.

\section{REFERENCE}

Ashworth, P., Bannister, P., \& Thorne, P. “Guilty in Whose Eyes? University Students' Perceptions of Cheating and Plagiarism in Academic Work and Assessment." Studies in Higher Education 22, no. 2 (1997): 187-203.

Barnhart, R.K. Chambers Dictionary of Etymology. Edinburgh: Chambers, 1988.

Carroll, Archie B., and Ann K. Buchholtz. Business \& Society. Ohio: South-Western Cengage Learning, 2009.

Eret, E. and Gokmenoglu, T. "Plagiarism in Higher Education: A Case Study with Prospective Academicians." Procedia - Social and Behavioral Sciences 2, no. 2 (2010): 3303-3307.

Laeheem, K. "Causal Relationships between Religion Factors Influencing Ethical Behavior among Youth in the Three Southern Border Provinces Of." Children and Youth Services Review (2019): 104641. https://doi.org/10.1016/j.childyouth.2019.104641.

Nash, Laura. Good Intentions aside: A Manager's Guide to Resolving Ethical Problem. Boston: Business School Press, 1990.

Sarlauskiene, L. and Stabingis, L. "Understanding of Plagiarism by the Students in HEIs of Lithuania." Procedia - Social and Behavioral Sciences 110 (2014): 638-646.

Schutz, A. The Problem of Social Reality. Dordrecht: Kluwer Academic, 1990.

Sutherland-Smith, W. "Pandora's Box: Academic Perceptions of Student Plagiarism in Writing." Journal of English for Academic Purposes 4, no. 1 (2005): 83-95.

Weiss, Joseph W. Business Ethics. California: Berett-Koehler Publishers, 2014. Wilhoit, S. Helping Students Avoid Plagiarism. College Teaching, 42., 1994. 